\title{
Identity and Social Othering: A Case Study on Youth in Turkey
}

\author{
Mehmet Birekul \\ Assoc. Prof. Dr., Necmettin Erbakan University, Faculty of Social Sciences and Humanities, Sociology Department, Konya, \\ Turkey, mbirekul@erbakan.edu.tr
}

\begin{tabular}{|c|c|}
\hline Article Info & ABSTRACT \\
\hline $\begin{array}{l}\text { Keywords: } \\
\text { Identity, } \\
\text { Social othering, } \\
\text { Othering, } \\
\text { Youth, } \\
\text { Construction of } \\
\text { identity. }\end{array}$ & $\begin{array}{l}\text { Multidimensional and original structure of identity, which prompts researchers to maintain interdisciplinary } \\
\text { studies, have made this concept one of the most complicated and problematic issues in social sciences literature. } \\
\text { Even though it is identified as features, characteristics, and indications regarding 'human as a social being' and it } \\
\text { is based on some components such as common language, culture, geography and history; identity is a special } \\
\text { historical condition of the contact with the 'other'. From this point of view, as an existential fact unique to } \\
\text { communities, identity develops with an interaction by referring to counterpart, i.e. 'other'. At this point, it is } \\
\text { understandable that 'othering' becomes one of the methods that help to construct the identity. } \\
\text { In Turkish society, examining 'other' brings some reflexes on the process of creating identities mentioned above. } \\
\text { Especially, either receiving someone's existence completely or ignoring him slightly in communication process } \\
\text { demonstrates radical biases of identity. From this point forth, current study focuses on young people, who are the } \\
\text { dynamic groups of society, and tries to discover their attitudes towards ideas, ideologies, or beliefs in terms } \\
\text { identity crisis. As the main discussion point, it is assumed that psychological othering process among young } \\
\text { people is likely to become social othering among the members of society. In order to explore this assumption, a } \\
\text { qualitative research that samples young people in Konya city was conducted. Unstructured one-by-one interviews } \\
\text { were applied to young people in order to get in-depth information regarding the issue. Data was analysed under } \\
\text { some themes that would appoint the aims, scopes and the problems of the study. As the main findings of the } \\
\text { research, it can be asserted that although othering process in individual basis may not cause serious problems } \\
\text { among young people, transforming otherization to social milieu and excluding groups in a social background } \\
\text { would pose some problems among young people. }\end{array}$ \\
\hline
\end{tabular}

\section{Kimlik ve Sosyal Ötekileştirme: Türkiye’de Gençlik Üzerine Bir Durum Çalışması}

\begin{tabular}{|c|c|}
\hline Makale Bilgileri & ÖZ \\
\hline Makale Geçmişi & Kimliğin, araştırmacıları disiplinlerarası çalışmaları yürütmeye teşvik eden çok boyutlu ve özgün yapısı, bu \\
\hline $\begin{array}{l}\text { Geliş: } 01.05 .2020 \\
\text { Kabul: } 12.06 .2020 \\
\text { Yayın: } 31.12 .2020\end{array}$ & $\begin{array}{l}\text { kavramı sosyal bilimler literatüründeki en karmaşık ve sorunlu konulardan biri haline getirmektedir. 'Sosyal bir } \\
\text { varlık olarak insan'a ilişkin özellikler, karakteristikler ve göstergeler olarak tanımlanıp ortak dil, kültür, coğrafya } \\
\text { ve tarih gibi bazı içerikler üzerine kurulu olsa da kimlik, 'öteki' ile kurulacak bağlantının özel bir tarihsel durumu } \\
\text { olarak ortaya çıkar. Bu bakıştan hareketle, topluluklara özgü varoluşsal bir gerçeklik olarak kimlik, karşı tarafla }\end{array}$ \\
\hline Anahtar Kelimeler: & $\begin{array}{l}\text { yani öteki ile kurulacak irtibat gelişmektedir. Bu noktada, ötekileştirmenin, kimlik inşasına yardımcı olan } \\
\text { metotlardan biri olduğu anlaşılabilirdir. }\end{array}$ \\
\hline $\begin{array}{l}\text { Kimlik, } \\
\text { Sosyal ötekileştirme, } \\
\text { Ötekileştirme, } \\
\text { Gençlik, } \\
\text { Kimlik inşası. }\end{array}$ & $\begin{array}{l}\text { Türk toplumunda 'öteki'nin incelenmesi, yukarıda bahsedilen kimliklerin inşa sürecinde bazı refleksleri } \\
\text { beraberinde getirmektedir. Özellikle birinin varlığını tamamen kabul etmek ya da onu keskin bir şekilde } \\
\text { görmezden gelmek kimliğin radikal yönelimlerini ortaya koymaktadır. Buradan hareketle, mevcut çalışma } \\
\text { toplumun dinamik bir grubu olarak genç bireyler üzerine odaklanmakta ve bu grubun kimlik krizleri açısından } \\
\text { tutumlarını fikirler, ideolojiler ve inançlar doğrultusunda keşfetmeyi amaçlamaktadır. Temel tartışma noktası } \\
\text { olarak, gençler arasındaki psikolojik ötekileştirme sürecinin toplum üyeleri arasında sosyal ötekileştirme } \\
\text { eğiliminde olduğu varsayılmaktadır. Bu varsayımı araştırmak için Konya'da yaşayan gençlerin üzerinde nitel bir } \\
\text { araştırma yapılmıştır. Konuyla ilgili derinlemesine bilgi edinmek için yapılandırılmamış bire bir nitel görüşmeler } \\
\text { gerçekleştirilmiştir. Veriler çalışmanın teorik arka planına uygun ve çalışmanın problemini yansıtabilicek temalar } \\
\text { 1şı̆ı̆ında analiz edilmişţir. Çalışmanın temel bulgusu, kişisel bazdaki ötekileştirmenin gençler arasında büyük } \\
\text { problemlere yol açmadığı ancak ötekileştirmenin sosyal alan bağlamında ortaya çıkmasının ve sosyal grupların } \\
\text { dışlanmasının genç bireyler arasında problem doğurduğudur. }\end{array}$ \\
\hline
\end{tabular}

Atıf/Citation: Birekul, M. (2020). Identity and Social Othering: A Case Study on Youth in Turkey, Journal of Civilization and Society, 4(2), 118-127. 


\section{INTRODUCTON: IDENTITY AND OTHERING}

As it is known, multidimensional and original structure of identity, which prompts researchers to maintain interdisciplinary studies, has made this concept one of the most complicated and problematic issues in the social scientific literature (Türkbağ, 2003, p.209). As Lawler clearly stated, "identity is a difficult term; more or less everyone knows more or less what it means, and yet its precise definition proves slippery" (Lawler, 2008, p.1). In order to deal with such a complicated issue or understand it in a clearer way, some of the technical information regarding etymological roots of identity could be discussed here. In this way, it would be possible to highlight the crucial points in terms of identity, other, othering, i.e. the main conceptual framework of this field work.

The origins of the term of identity in Latin, which is 'identitas', means 'being the same' or 'being exact'. It, in this respect, appears as a social fact resulted from the formation of individual as a social being. In other words, it is identified as features, characteristics, and indications regarding 'human as a social being'. It is also based on some components such as common language, culture, geography and history. On the other hand, identity is a special historical condition of the contact with the 'other', which makes individuals 'different', 'unequal', and so 'identified' (Dağı, 2002, p. 13). For a comparison, experiences regarding ourselves are always unstraightforward. However, our experiences towards 'others' are always immediate. We always need a mirror to see our 'selves' as much as we need it to see our own faces. Such a reflection includes realization and awareness. That is why; our relationships with the other represent our relationships with ourselves, too (Assmann, 1995, p. 130). That is why; identity reflects plural structure and includes other identities, as well.

To apply the Latin, which gives the shape of today's modern European languages, the opposite of other in this language is 'alius' (or 'alia' and 'aliud'). Remarkably, this word is coming from the word of 'alien' in English. The other Latin opposite for 'other' is 'ceterus' and it means 'rest' in English. Etymologically, 'alien' represents the other; and other represents the areas of differences, the cellar of fears and concerns. Especially, othering in terms of race, gender, and class is something actively polarizes the society. In some conflicts such as White - black, masculine - feminine, West - East, one of the values or factors among these becomes "dominant" and the other one becomes "dependent" identity. A strong identity, by its nature, would try to set up a bad, irrational, abnormal, intrinsic, mad, sick, beast, dangerous -so other- by emphasizing some of the differences (Nahya, 2011, p. 29). In this sense, difference is recognized as the effect of other. In the light of these arguments, it could be said that identity needs other to survive and in order to secure itself slightly; it converts "difference" to "othernesses" (Selçuk, 2012, p. 78).

After considering the etymological background of identity and other, sociological reflections of this concept can be brought into discussion. Firstly, it can be inferred from the importance of 'other', which is the subject of second- or third or more-people's inclusion, that identity ontologically keeps social background. Even considering identity formation requires the community or multi-dimensional relationships with the other members of any social formation. Taking family into consideration, for example, gives important clues about the social background of identity. Since a child has been aware of himself, people around him teach him who he is and what he need to do or not to do basically. In this process, individuals reflect their own experiences and expectations as well as the expectations and patterns of society (Galvin, 2006). Such a dual relationship encourages us to admit that neither family nor society can solely be affective on children's identity formation. Cigoli and Scabini (2006, p. 68) discuss the togetherness of family and society on the formation of identity via following statements: "both the family and society are responsible for what happens, and both are in a position to influence each other. In short, both play a part in how individuals and generations develop and grow, and both should be held responsible".

At this first level, as you shall guess, other becomes a natural and neutral element for identity formation. This means that, without any conflict or opposition, other in family life becomes a platform where individual obtain some certain types of behaviours and discourse. In other words, society appears as a smooth source in family where individual initially gain specific characteristics and roles in a linear way. However, the second level for identity formation makes other a counterpart and opponent in some 
cases, so nonlinear or reciprocal ways that include negative reactions among individual and society become more visible.

This position is the crucial point in terms of the most well-known 'problematic' of identity, which is 'other'. Without any 'other', no identity can be constructed (Andreouli, 2010). As discussed in the case of family, baby identifies itself by identifying and/or recognizing others, which are mother, father or brother/sister (Lewis and Brooks-Gunn, 1979) . This means that from the first year to the end of his/her life, one will definitely identify one or more 'other'(s) when maintaining her/his life. On the other hand, in time, as soon as individual recognizes himself, formation of 'other' as much as 'self' becomes much more complicated. The main reason behind this complex structure of the two sides of identity, self and other, is mainly about the changing and diversified relationships among individuals or individual and society in modern World (Giddens, 1991). For a student, for example, teacher becomes one of the most visible 'other'. Or, for an employee, boss becomes an 'other'. For a more complicated comparison besides economic or educational processes, some of the moral and imaginary structures show themselves. Nationality, race or ethnicity in modern time is one of the most important background in terms of the formation of 'self' and 'other'. Especially in multi-cultural societies, due to intensive encounters among the members of different ethnicities (Murdock, 2016), individual keeps their own cultural/ethnic reflexes alive as much as they keep the image of other alive in daily life. In relation to this, in order to protect himself and those who share the same ethnicity with him, individual ontologically otherize the members of the 'other' ethnic culture. The symbols, discourse, structures, etc. belong to 'other' ethnic culture are known and internalized as much as one's own symbols, etc. are known and internalized. This also causes strong in-group dynamics that supports the members of any ethnic culture in terms of unity and collaboration (McRae \& Short, 2010). Without otherizing the counterpart, it is almost impossible to sustain the cultural life of any ethnic group.

That point is the problematic and dangerous side regarding identity and individual. Of course, it is very normal and ontologically expected situation that people otherize each other when constructing and empowering their identities and of course other must be over there to strengthen in-group dynamics. However, as a very common trap, ontological othering process could give place to 'social othering process". Social othering, which will be detailed in the next section, is based on intentional and even artificial behaviours directed against others. By this background, problems about living together in a multi-ethnic or cultural society arise. Now, this concept can be clarified in a more detailed way in order to distinguish it by initial othering process.

\section{SOCIAL OTHERING}

Sociological approach requires examining 'preferred dimensions' of identities as well as 'given dimensions' of this concept. Everyone holds different and nested identities. Individuals' consciousness or struggle on identity types is based heavily on his socialization process of the group he lived in. It means that every social movement has a 'consciousness policy' applied on an audience. One of the typical examples for this is Marxist class consciousness. By distinguishing 'class in self' and "'class for self", Marx clarifies the difference among one who has the class consciousness and who has not, in a philosophical context. However, Marx insults the workers who do not fit for his definition on class consciousness. He accuses these types of 'lumpen' workers as being 'proletariat in self', so not being able to demonstrate the behaviours fit for the 'status of worker'. Obviously, Marx seeks for a correspondence among "an objective situation resulted from a target group" and "an identity he defined". Defining political values or behaviours of women through female identity would be a relevant example for Marxist approach on identity.

However, all of these expectations are not determiner on people's own definitions on their identities. That is why, for individuals, the important point becomes 'how they recognize themselves' besides 'what they are'. In other words, one's perceptions on himself and the reasons that bring him to these perceptions such as experiences, etc. would be very important on his identity. This perceptions and relationships/experiences are formed in these perceptions (and eventually) determines the one's positioning the others culturally and politically. In this respect, the 'other' as the descriptive of political and cultural identity is one of the key concepts of modern discourses on identity. In social relationships, 
the problem of 'being marginalized' or 'being other', which is forced by dominant culture or other dominant similar groups, represents a different form of social discrimination. It is seen, once again, that construction of identities is possible with defining another.

On the other hand, people, who are 'otherized' or 'oppressed' by dominant culture, could be misunderstood because of their struggle against these implementations over them and generally, they are named 'divider', 'separatist', etc. This process definitely feeds othering more and more. Social dynamics that are based heavily on antagonistic approaches become more visible. Other at this level is recognized as a dangerous piece of society which supposedly will become harmful for dominant ethnic or religious group in society. Symmetrically, those who are socially otherized become marginalized and they form their identity on the basis of being socially otherized. Beyond the ontological otherizing process, such othering brings unwanted and unexpected consequences such as conflict in different levels, political turmoil, ethnic cleansing, terror, even clashes and wars. Although every social othering process does not necessarily cause such negative consequences, most of the conflicts and clashes in today's World are originated from social othering processes. Not only the clashes between different countries, but also the conflicts among the ethnic cultures living in the same country are the cases for social othering. As it will be discussed in specific to young people in Turkey, governments struggle with extremist nationalist movements among the ethnic cultures they govern in a country. Perhaps, it is the hardest issue to manage because of closeness of different ethnic cultures and state's role as a mediator. On the other hand, negative manners rooted in identity against other becomes another big issue. As Yardım states, "Once hate turns a part of an identity, that identity cannot identify itself independent on the group subject to hate" (Yardım, 2015, p. 115). Such conflicts and antagonisms continue if any precaution is not taken. As a result, until recognizing the differences in the light of the ethics of multiculturalism, giving some rights to minorities or developing human rights would not be possible. On the contrary, social differences would be widened and antipathy among social groups would appear. Especially, in the case of being insufficient on embracing ethical values regarding other, it is seen that the order and discourse of education would not be enough (Aktay et al., 2010, p. 21).

To sum up, it could be said that difference and othering as the 'construction of the identity' is a necessity for the identity achievement of the individuals. However, if an individual tends to destroy someone else's identity when constructing his own, some of the social problems would definitely come up. As it has been mentioned many times so far, such a process causes an identity crisis. This crisis, which we could name as social othering, demands a 'sterilization' of other ethnicities, sects, religions, or any ideas from the social platform. Finally, othering becomes a tool for oppression instead of a platform that balances differences in social environment.

\section{METHOD}

In this study, in order to explore the problems, which are basically on "identity" and "othering", i.e. problems socially constructed and deeply meant, qualitative research methods and techniques have been used (Silverman, 2018, p. 8). For the data collection, unstructured interviews have been applied to research sample. The sampling strategy of the research is based heavily on the diversity of the origins of participants (hometown, ethnic background, etc.). By this, participants currently living in Konya city, who are originally from different cities of Turkey, were approached. In addition, it was considered that selection of young people between the ages of 19-25 would help researcher to better reflect young people's point of views on research subject.

Verbatim transcription of recorded answers of the participants have been preferred in order to code the data and discuss relevant passages (Bloor and Wood, 2006, p. 29) under specific themes of the study.

\section{ANAYLSES AND FINDINGS}

To analyze again, our study assumes that "recognizing othering as a social problem" instead of "the construction of the identity" brings identity crises among young people. As a problem that has been experienced in many societies, this research proposes to show this issue in specific to Turkish society and youth. To remember again, in this research, qualitative approach and techniques were benefited. Data was collected by maintaining qualitative in-depth interviews with twenty-four (24) young people, who live in Konya City, between the ages of 18 and 25 in 2019. Young people were chosen because it was assumed 
that they are mostly (and deeply) affected by the crises of identity during their socialization process. On the other hand, when young people were included to research, it was considered to choose them from different ethnicities, worldviews, social and cultural environments.

Table 1. Background of Participants and Sentences on How do they Identify Themselves

\begin{tabular}{|c|c|c|c|c|c|}
\hline & $\begin{array}{l}\text { City of } \\
\text { Birth }\end{array}$ & Gender & Age & $\begin{array}{l}\text { Level of } \\
\text { Education }\end{array}$ & How would you define yourself by referring an identity? \\
\hline 1 & Osmaniye & M & 23 & University & $\begin{array}{l}\text { An earthman. Not a member of any race but the sole member } \\
\text { of human race. Something like the other people are just objects } \\
\text { beside me. }\end{array}$ \\
\hline 2 & Karaman & $\mathrm{F}$ & 22 & University & $\begin{array}{l}\text { Firstly Turkish. My Turkish identity has the priority in } \\
\text { compare to others. }\end{array}$ \\
\hline 3 & Konya & $\mathrm{F}$ & 22 & High School & Muslim, The Citizen of Turkish Republic. \\
\hline 4 & Manisa & M & 25 & University & $\begin{array}{l}\text { Someone lives in his own World, independent from every } \\
\text { clicks or groups around me and wants to understand the } \\
\text { Universe. }\end{array}$ \\
\hline 5 & Mersin & $\mathrm{F}$ & 24 & University & Kemalist, Turkish, Alawite. \\
\hline 6 & Van & M & 24 & University & $\begin{array}{l}\text { Ethnically Kurdish. Religiously Muslim, Sunni and Shafii. As } \\
\text { the national identity, I am a citizen of Turkish Republic. In } \\
\text { addition, I am coming from a traditionalist environment but in } \\
\text { some cases, I keep pace with modernism. }\end{array}$ \\
\hline 7 & Niğde & $\mathrm{F}$ & 22 & University & $\begin{array}{l}\text { Ethnically Turkish, Religiously Muslim, As the sect: Hanafi, } \\
\text { Nationally Turkish Citizen }\end{array}$ \\
\hline 8 & İskenderun & $\mathrm{F}$ & 24 & University & I define myself as Muslim and would also like to add Juruk. \\
\hline 9 & Konya & $\mathrm{F}$ & 22 & University & $\begin{array}{l}\text { Ethnically Turkish, Religiously Muslim, As the sect: Hanafi, } \\
\text { Nationally Turkish Citizen }\end{array}$ \\
\hline 10 & İskenderun & $\mathrm{F}$ & 23 & University & $\begin{array}{l}\text { I am Turkish. I am originally Arabic but feeling myself } \\
\text { Turkish. I am the citizen of this country, living in this country, } \\
\text { my language my education, etc. I feel myself definitely } \\
\text { Turkish. }\end{array}$ \\
\hline 11 & Konya & M & 23 & University & $\begin{array}{l}\text { I define as Muslim and also, I am Turkish. But my religious } \\
\text { identity is stronger. }\end{array}$ \\
\hline 12 & Sivas & M & 21 & University & $\begin{array}{l}\text { I am from Turkish nation. When saying Turkish, Muslim } \\
\text { identity becomes clear anyway. That is why I firstly use the } \\
\text { term of Turkish. }\end{array}$ \\
\hline 13 & Konya & $\mathrm{F}$ & 19 & High School & Muslim, Turkish \\
\hline 14 & Konya & $\mathrm{F}$ & 22 & University & Muslim \\
\hline 15 & Antalya & M & 23 & University & $\begin{array}{l}\text { If I need to define myself, I would do it by saying Turkish. But } \\
\text { I don't do it in a racial belonging, but I would define by } \\
\text { considering cultural ties. If someone asks me who am I, I } \\
\text { would unfortunately say Turkish. There is a situation like "I am } \\
\text { Turkish, but I am not". "I am Muslim, but I am not". }\end{array}$ \\
\hline 16 & Konya & M & 21 & University & $\begin{array}{l}\text { I define myself Turkish. Recent developments on Kurdish } \\
\text { issue, I more strongly define so. }\end{array}$ \\
\hline 17 & Konya & $\mathrm{F}$ & 20 & University & $\begin{array}{l}\text { I don't mention my Turkish or Muslim identity when defining } \\
\text { myself. But if it is necessary, I would say a Turkish Muslim. } \\
\text { But Muslim identity has the priority. }\end{array}$ \\
\hline 18 & Mersin & $\mathrm{F}$ & 24 & University & $\begin{array}{l}\text { As a Human. My Muslim or Turkish identity is not in the } \\
\text { foreground. If I have to introduce myself, I would do it by } \\
\text { saying 'human'. }\end{array}$ \\
\hline
\end{tabular}




\begin{tabular}{|c|c|c|c|c|c|}
\hline 19 & Sivas & M & 25 & University & I am a Muslim Turkish. \\
\hline 20 & Kastamonu & $\mathrm{F}$ & 22 & University & I define myself Muslim. \\
\hline 21 & Almanya & $\mathrm{F}$ & 22 & University & $\begin{array}{l}\text { I am someone who is respectful to the behaviours and beliefs } \\
\text { of people and express her ideas about the other people in a } \\
\text { respectful way. }\end{array}$ \\
\hline 22 & Konya & M & 25 & University & Activist Turkish and Hanafi Muslim. \\
\hline 23 & Karaman & $\mathrm{F}$ & 22 & University & $\begin{array}{l}\text { Firstly, I define myself Turkish. My Turkish identity has the } \\
\text { priority in compare to others. }\end{array}$ \\
\hline 24 & Bursa & $\mathrm{F}$ & 22 & University & $\begin{array}{l}\text { On my National ID, I am called Turkish and Muslim. This is } \\
\text { how people define me. }\end{array}$ \\
\hline
\end{tabular}

In the interviews, it was proposed to shed light on

1) whether young people could clearly identify themselves,

2) how do young people position themselves towards the others, who have different status in terms of ethnic and/or religious background?

3) what are the perceptions of young people on a multicultural society?

\section{Ethnic and Religious Background on Identities}

In the interviews, it was primarily observed that the majority of the participants of the research preferred to put the emphasis on religious and ethnic belonging when identifying themselves. Identities of Turkish or Kurdish and Muslim become the most frequent answer to the question of "How do you identify yourself as identity?'. It is also evident that when some participants prioritize the Muslim identity and put the Turkishness or Kurdishness on the second order, it was also encountered that participants identify themselves by referring to their religious sects and citizenship. The answer given by a university student could show this multiple identification: Male).

“Ethnically Turkish, Religiously Muslim, as the sect: Hanafi, Nationally: Turkish Citizen.” (22,

This approach can also be encountered among "Kurdish Muslim" participants. Another university student states that:

"Ethnically Kurdish. Religiously Muslim, Sunni and Shafii. As the national identity, I am a citizen of Turkish Republic." (24, Male).

On the other hand, ethnic and religious emphasis could be seen on the answers of the other participants:

"I am from Turkish nation. When saying Turkish, Muslim identity becomes clear anyway. That is why I firstly use the term of Turkish." (21, Male).

A shorter and clear answer is given by a female participant of the research:

"I am a Muslim Turkish." (Female, 25). ethnicity:

Another female participant clarifies her priority when defining herself in terms of identity through

“Firstly Turkish. My Turkish identity has the priority in compare to others.” (Female, 22).

From the data related to first references when making an identification, it can be asserted that ethnic belonging, nation-state formation and religious beliefs are the most effective factors among young people who were asked to define themselves.

From this point forth, it is clear that ethnic belongingness as one of the most frequent and popular outputs of identity in modern times (Yan1k, 2013, p. 231) appears as a strongest reference point for the participants of this research. As it can be observed on Table 1 above, except for several responses, they define themselves by referencing to their Muslim, Turkish or Kurdish background. 
On the other hand, in some cases, young people tend to identify themselves by combining ethnic and religious perceptions. For example, "Muslim Turkish" is the frequent combination of identity formation among Turkish participants.

This side of the research and the relevant answers by the sample shows that young people are more likely to clearly identify themselves, which could also be an answer to research question one.

\section{Problems Regarding “Identifying” Among Young People}

During the qualitative field research, it has also been observed that young people have difficulty in identifying themselves clearly in some other cases. It shows that especially multi-layered and multifaceted structure of identity makes these young people confused about putting precise statements while identifying their identities. At this point some of the passages from the interviews can be inferred. For example, the answers for the questions of "Could you say that you can easily identify yourself as identity?" and "If so, how would you identify?" were very remarkable.

A university student says that

"No, I cannot identify myself as identity because I am someone who is so mixed-up. That is why; my answer could change for different circumstances and places. I just want to identify myself without considering any social apprehension or how I seem." (23, Male)

Similarly, another university student states that

"No, I cannot easily identify myself in this country. If I try to do so, big discussions are happening, and talks become a discussion. I just want to define myself someone who is dedicated to scientific studies, who is avoiding from alignments and who believes the irrationality of conflicts among ideas. However, everyone whom I talked is trying to make me someone who is supporter of this or that." (22, Male)

For these participants, it becomes clearer that changing structure of identity, on the other hand, visibility of the "others" in certain places or atmospheres cause "hesitation" among youth in terms of clarifying their identities in a certain level.

Another student, on the other hand, says that

"I already define myself Muslim and Turkish but whenever I share a different milieu with the others; it becomes harder for me to identify myself as I did. In these cases, I prefer to keep quiet." (19, Female)

For this participant, possible multicultural atmosphere where she shares with the other people belong to different cultures, religious background, etc. push her to avoid position herself beside her own identity freely. From the answers given by the participants below, it can be asserted that young people hesitate to identify themselves because most probably of the danger of being "otherized". The answers generally emphasize that identifying and ethnic or religious identity would definitely bring the other identities on the agenda among young people, so they feel uncomfortable while taking a part in terms of freely expressing their views and manners on identity.

At this point, it can be concluded that when some of the participants clearly identify themselves by referring their ethnic and/or religious identities, other young people interviewed for this research feel some hesitations as making a clear explanation for their identities. In relation to this, it becomes clearer that the sense of belonging among these participants to their ethnic or religious groups is not strong than the others who easily identify themselves without any reservation.

\section{Another Problematic Issue: Intolerance to "Other" Shown in Social Milieu}

Interestingly, although young people were complaining about difficulties in demonstrating their own identities, they also become intolerant when the 'others' would like to make their identities visible in social platforms. For instance, the answers to the question of "Is that annoying for you that the people could easily demonstrate the arguments, which could represent their identities, such as flag, badge, tattoo, etc.) could be examined.

One of the young people says that: 
"To be honest, because I am a Kurdish, I have been exposure such processes (oppression, labelling, etc.) by my Turkish friends and I felt so upset. When they were stubbornly showing the badges that symbolize Turkish flag, I felt so upset for not in terms of the flag but because of the action that they demonstrated. I am a Kurdish and I would not show the badge, or anything symbolize my flag, etc. and I would not do it in a threatening manner. Actually, I have many friends who have tattoos show Atatürk on their arms, put many political symbols, etc. but I have never disturbed because of this. However, I felt so annoyed when the others stubbornly show me the symbols. They are harassing people in this way." (21, Male)

Another young person answers that

"It makes me feel uncomfortable because showing something regarding identity means that they want people to be like them and this is something unacceptable." (20, Female)

One of the other participants believes that such arguments or symbols could keep an ulterior motive:

"Indeed, it does not make me feel uncomfortable; however, in today's Turkey, if such an action or behaviour is shown, there must definitely be an ulterior motive behind that. I think that there is a motivation for provoking disturbance. For that reason, it could be irritating." (22 Male)

Another young person's response demonstrates social othering as the consequence of presenting symbols that refer to identity:

"Actually, I feel a bit annoyed when seeing such symbols. For example, the biggest argument is headscarf. I don't ask them (women) to take it off but I feel sorry. Or young extremist nationalists (Supporters of Nationalist Movement Party), who are loudly walking on the streets with their flags on their hands... They should not do this. They don't have to do this. I cannot understand why the hell are they coming together under a party? I feel myself I lost in the thoughts. Perhaps, the concept of 'label' could be helpful to clarify this issue. If these symbols -or arguments as you said-become a label, if people shout by the motivation of these symbols and saying, "This is who am I", then I feel so disturbed. Because if quality decreases, the label increases. People who are unqualified apply such symbols." (23, Female)

In these cases, symbols become the means on othering people, especially those who are from different ethnic or religious background. Peers who menacingly carry these symbols and show the people from other ethnic or religious background demonstrate a socially constructed othering process through items. At this point, Turkish flag is used by Turkish young people to otherize Kurdish people, on the other hand, headscarf become a symbol that may disturb other young people, etc. It was founded by these examples that emphasizing or being exposure to these symbols in social milieu make young people feel disturbed and develop a manner that would socially otherize the members of different religious or ethnic groups.

Under this theme, one of the theories in mainstream literature on identity, ethnic background, othering can be re-visited. The place of symbols and symbolization on identity formation in communities (Cohen, 2000) can be a reference point for the data. Accordingly, people construct their identities through such symbols. This means that, the counter part of identity, which is other, can also be detected by encountering the symbols of other cultures/communities. For this research, participants who feel discomfort when they encounter the symbols of different groups and communities react similarly. This finding is also an answer to the research question "how do young people position themselves towards the others, who have different status in terms of ethnic and/or religious background?".

\section{Hidden Agenda: Invisible Support to Social Othering}

In society, different groups, regardless of their extent in terms of human capacity, members, political position, etc., are generally supposed to have a hidden agenda. This agenda is generally accused as being opposed to national security, the welfare of the community or, in some cases, the authenticity of the dominant religious belief in society. For that reason, the member of these groups can be otherized by the members of dominant ethnic or religious group in country or society due to such prejudices. 
This frame is valid for the current research, too. For young people, the others always have a hidden agenda. In this respect, young people believe that others always 'otherize' them. One of the most striking passages could be examined at this point. For the young lady, different ethnic and religious groups have a hidden agenda that threats the country:

"For example, some of the religious communities threat the state authority by benefitting from religion. They have some hidden policies over the state. I believe that, on the other hand, Greeks and the other groups ethnically have some harmful targets." (22, Female)

Greeks as one of the official minority ethnic group in Turkey become a threat in this case. However, in addition to long-term minority status of Greek people in Turkey, Syrian people, who have started to live in Turkey since 2011, might be perceived a threat and theoretically being otherized by young people in Turkey:

"I am really concerned that Syrians become a threatening factor day by day because they have very difficult position. Difficult position, destituteness and hunger definitely push people to commit crime. If they get organized, they really might be harmful for the country. Prostitution, mafia, drug and similar business they might be involved in... Our country's social structure is not sufficient to prevent this."(22, Female)

Another young lady puts that:

"For example, some tarikats (which are some sort of religious sects) are secret threats. If Syrians settle down to Turkey, they may announce their own candidate on elections." (19, Female)

In relation to hidden agenda process, a 22-year-old male participant reveals his discomfort about foreign languages spoken in public sphere by referring some specific languages when answering the question of "Can another language (for example Arabic or Kurdish) be commonly used in Turkey?":

"Not, it should not be used. Even in state departments, there must be one language. In the street, English can be spoken because we can understand it at least to some extent. But not Arabic or Kurdish. For example, in public transport, I have to understand what people, whom I do not know personally, talk about if they speak out." (22, Male)

Lastly, another male participant $t$ makes strict comments, where social othering process can easily be observed, when answering the question of "Do you think, is there a hidden agenda of different ethnic and religious groups in Turkey that threaten the country?":

"I am definitely sure that some of these groups have such ideas. Even these are the thing apparently mentioned in media, not hidden. Whereas these groups are connected with foreign countries and they are in a position of curling iron, they are benefited by foreign countries against their own country." (25,Male)

According to common data investigated in this theme, political background and consequences of identity and its relationship the other becomes more visible. This point is actually a platform where we could observe the reflections regarding social othering. When the focus is directed on groups that assumingly keep hidden agendas or groups who threaten the other, an othering process that directly targets specific social groups come into the picture. Although responses that generate the data of the previous themes seem more moderate against other, identity-based interpretation of the groups and recognizing these groups as danger can obviously be attributed to social othering.

\section{CONCLUSION}

We can finally say that "other" is one of the factors that help us on constructing our own identity. On the other hand, we organize our "selves" by looking at other. At this point, by having difficulties in presenting their identities because of the fear of social exclusion, young people experience an identity crisis. In the case of Turkey, this could be exemplified. As a research finding, I can easily claim that "young people, who avoid demonstrating the symbols regarding their own culture, also feel disturbed from the other's cultural symbols or cultural expressions. It brings the paranoia, which seeks for a hidden agenda kept by "others", so young people cannot be tolerant to others, who do not think or act as they do. 
This finding appears in Turkish case lets us critically evaluate the "salience theory" in the construction process of identity. "Social identity theorists originally used term salience to indicate the activation of an identity in a situation" (Stets \& Burke, 2000, p. 229). It, as you shall see, basically assumes the active participation and appearance of identity in social milieus. However, in Turkish case, young people generally seem to in-activate their behaviours, values, etc. regarding their identity in social interaction processes.

It should also be noted that during the interviews, there were some young people who are very clear about their identity and dedicated to explaining this. The main reason or prompter behind this could be explained by referring to "self-fulfilment". These young people realized themselves despite overwhelming odds against society. In other words, despite identity crises in society, they are able to keep their identities and internalize multiculturalism. For the last words, having difficulties in positioning the "other" in the light of presenting the identity proves an identity crisis among young people.

\section{REFERENCES}

Aktay Y., Kızılkaya A., Osmanoğlu E., Dilek K., \& Yurdakul S. (2010). Türkiye'de Ortak Bir Kimlik Olarak Ötekilik, Ankara: Eğitim-Bir-Sen Yayınları.

Andreouli, E. (2010). "Identity, Positioning and Self-Other Relations". Papers on Social Representations, 19, pp. 14.1-14.13.

Assmann, J. (1995). Collective Memory and Cultural Identity, Translated by John Czaplicka, New German Critique, 65, pp. 125-133.

Bloor, M., \& Wood, F. (2006). Keywords in Qualitative Methods a Vocabulary of Research Concepts. London: Sage.

Cigoli, V. \& Scabini, E. (2006) The Family Identity: Ties, Symbols, and Transitions. London: Lawrence Erlbaum Associates, Publishers.

Cohen, A. P. (2000). The Symbolic Construction of Identity. London: Routledge.

Dağı, Z. (2002). Kimlik, Milliyetçilik ve Dış Politika Rusya’nın Dönüşümü. İstanbul: Boyut Kitapları.

Galvin, K. M. (2006) Diversity's Impact on Definig Family: Disourse-Dependence and Identity. IN The Family Communication Sourcebook, Eds: Lynn H. Turner \& Richard West, London: Sage Publication, pp. 3-20.

Giddens, A. (1991). Modernity and Self-identity: Self and Society in the Late Modern Age. Stanford: Stanford University Press.

Lawler, S. (2008). Identity: Sociological Perspectives. Cambridge: Polity Press.

Lewis, M. \& Brooks-Gunn, L. (1979). "Toward a Theory of Social Cognition: The Development of Self". New Directions for Child and Adolescent Development, 4, 1-20.

McRae, M. B. \& Short, E. L. (2010). Racial and Cultural Dynamics in Group and Organizational Life. Los Angeles: Sage Publications.

Murdock, E. (2016). Multiculturalism, Identity and Difference: Experiences of Culture Contact. London: Palgrave Macmillan.

Nahya, Z. N. (2011). İmgeler ve Ötekileştirme: Cadılar, Yerliler, Avrupalılar. Atıllım Sosyal Bilimler Dergisi, $1(1)$, ss. $27-38$.

Selçuk, S. S. (2012). "Postmodern Dönemde Farklılığın Kutsanması ve Toplumun Parçacıllaştırılması: “Öteki” ve "Ötekileştirme”". Sosyoloji Araştırmaları Dergisi , 15 (2), 78-99.

Silverman, D. (2015). Introducing qualitative research. IN Qualitative Research: Theory, Method and Practice, D. Silverman (Edt.), London: Sage, pp. 3-14.

Stets, J. \& Burke, P.J., (2000). "Identity Theory and Social Identity Theory". Social Psychology Quarterly, 63 (3), pp. 224-237.

Türkbağ, A. U. (2003). "Kimlik, Hukuk ve Adalet Sorunu”. Doğu Batt, 23, ss. 203-218.

Yanık, C. (2013). "Etnisite, Kimlik ve Milliyetçilik Kavramlarının Sosyolojik Analizi". Kaygı. Uludă̆ Üniversitesi Fen-Edebiyat Fakültesi Felsefe Dergisi, 20, 225-238.

Yardım, M. (2015). "Hate Speech against Muslim Women: The Example of French and Belgian Francophone Media”. American International Journal of Social Science, 4 (5), pp. 115-127. 